\title{
A Comparative Study of Selected Public \& Private Sector Equity Diversified Mutual Fund Schemes in India
}

\author{
Dr. Vinay Kandpal ${ }^{1}$, Prof. P. C. Kavidayal ${ }^{2}$ \\ ${ }^{1}$ Assistant Professor, Department of Accounting \& Finance, University of Petroleum \& Energy Studies, \\ Dehradun, India \\ ${ }^{2}$ Head, Department of Management of Studies, Bhimtal, Kumaun University, Nainital, India
}

\begin{abstract}
This study is an effort to analyze the performance of selected Equity Diversified schemes with a view to see its impact on investor's decision making. In this study 18 Equity Diversified Mutual Funds schemes are taken as sample and the selection of schemes was on the basis of Corpus size and Returns of last 5 years. The risk free rate taken is 5.5\%. In order to give an increased return in domestic savings of investors and improvement in allocation of investment in different sectors, the need and scope for mutual fund as an investment option has increased immensely. Investment in Mutual fund is restricted to Tier 1 and Tier 2 cities whereas the rural and semi urban communities. One of the reasons behind it is lack of awareness in rural and semi urban areas. There is, therefore, a strong need for improving the awareness. The Private Sector Mutual Funds have recorded much better performance as compared to the Public sector Mutual Funds mainly due to better Funds allocation, better Management and efficient performance of Portfolio Manager. This result was arrived at after calculating and comparing the Sharpe, Treynor, beta and Jensen ratio.
\end{abstract}

Keywords: Mutual Fund, Beta, Standard Deviation, Sharpe's Index, Jensen

\section{Introduction}

Mutual Funds are essentially investment option where Asset Management Companies invest the funds invested by people with common investment purpose in different growing sectors. Investment in Mutual funds is managed by an efficient team of portfolio managers. They provide diversification, professional management and the ease of investment process for an investor who lacks the expertise in investment in capital market. With the introduction of a wide range of products, the mutual fund industry nowadays has a lot to offer to its investors. India is emerging as the next big investment destination, riding on a high savings and investment rate, as compared to other Asian economies. The house-hold segments have immense scope for attracting investments. Since opening up of the mutual fund to the private sector in 1990's the industry is adapting itself continuously to the changes that have come along. Assets under Management (AUM) have grown at CAGR of $28 \%$ over the last four years, slowing down only over the last two years, as fallout of the global economic slowdown and financial crisis. In present dynamic and changing market environment, mutual funds are looked upon as a transparent and low cost investment option which attracts the investor attention helping the growth of the industry. There is a strong need for improving the awareness especially among the semi urban and rural communities where they hardly know the benefits of investing in Mutual Funds. They are still investing in traditional investment options. It is important to study about the returns given by AMC Mutual Funds and analyse their performance.

\section{Objective of the Study}

In this study an effort has been made to analyze the performance of selected Equity Diversified schemes with a view to see its impact on investor's decision making. The major objectives of the study are as follows:

1. To examine the sensitivity of selected Equity Diversified Mutual fund schemes to the market fluctuations.

2. To compare and analyze the Equity-Diversified Mutual Fund schemes of select mutual fund players as suggested by Sharpe, Treynor and Jensen.

3. To compare the growth in Equity-Diversified Mutual Fund schemes with Industry average.

\section{Literature Review}

A description of the theoretical literature analysed is presented here to fix the basis for the study of risk involved in mutual fund returns and the need for regulating mutual funds. The works of Stigler (1971) and Posner (1969) discuss the general theoretical approaches to regulation. Stigler (1971) feels that the demand for regulation is not often for 'public benefit but rather for the benefit of the industry in question. The states coercive power allows it to tax, control entry, effect make policies which affect complements or substitutes or even fix prices. Such power; can be 'bought' by 'industries in' return for campaign funds to restrict competition or ensure 
profits. Stigler points out that such regulations are actually welfare-reducing as the benefits inefficient policies are possible only because in a democracy voting on each policy is costly and hence not done and also because not all voters who vote might have an 'interest' in the issue. Tullock (1975) downplays the need for regulation and believes that the costs of government failures or regulatory failures are larger than the cost of market failures. Markowitz (1952) was the first to propose the mean-variance analysis of portfolio decisions. He discussed the concept of efficiently diversified portfolios which maximized expected returns for a given amount of risk measured by variance. The concept of downside risk started with the publication of two papers in 1952. The first is "Portfolio Selection" by Markowitz, the second is "Safety first and the holding of assets. An investor will prefer safety of principal first and will set some minimum acceptable return that will conserve the principal. The initial study on Mutual Fund included the research contribution from Jensen (1968), Sharpe (1966) and Treynor (1966) using the capital asset pricing model to have a comparison of benchmark portfolio with that of risk adjusted returns of funds. The analysis done by Sharpe and Jensen concluded that the Mutual Fund underperform market indexes and made a recommendation that the returns were not enough to give the benefit the investors for the different charges they incur to invest in Mutual Fund. The pioneering works for determining the market timing and stock selection abilities of managed portfolios, were done by Treynor Mazuy (1966) and Henriksson Merton (1981), and later modified by proponents of the conditional approach (Ferson and Scadt, 1996). Friend, Brown, Herman and Vickers did a research on Mutual Fund considering 153 funds with data period 1953-1958 and created an index of standard and Poor's indexes of five securities with the elements by their representation in the Mutual Fund sample. Friends and Vickers (1965) in his research work analyzed that Mutual Funds have not performed superior to random portfolio. Sharpe, William F. (1966) suggested a measure for the evaluation of portfolio performance. Sharpe was among the earliest to use the CAPM to assess mutual funds performance. He assumed that expected return $E\left(R_{P}\right.$. $)$ of a fund and its risk are linearly related. Sharpe found that funds underperformed the Dow Jones index by 40 basis points. Further better performing funds had lower expense ratios. Sharpe examined the performance of 34 open end funds for the period 1954-1963 in the US. The results of his study concluded that good performance was associated with low expense ratio and not with the size. Sample schemes showed consistency in risk measure.

\section{Research Methodology}

Data Collection: The present research is a study of examining and analyzing selected mutual fund schemes by using different financial and statistical tools. The schemes taken for this purpose are Equity-Diversified Mutual Fund Schemes. This study compares 18 equity-diversified funds launched by public sector and private sector. The schemes have been selected using deliberate sampling method subject to the criteria mentioned as under:

a) Corpus size b) Returns of 5 years. c) Top 18 schemes ranked on the basis of 5 years compounded annualized returns.

Closing Net Asset Values of the selected schemes are taken on Monthly basis for calculating the desirable results. The study is exclusively based on secondary data, which has been collected from various websites, journals and fact sheets of various mutual fund schemes published by them time to time.

Tools \& Techniques: For the performance of the mutual fund schemes various measurement of the portfolio are used as beta, Sharpe Index, Treynor Index and Jensen Index.

Risk-Free Rate of Return $\left(\mathbf{R}_{\mathbf{f}}\right)$ : In this study, the weekly yields on 91-day Treasury bills have been used as risk free rate. $(5.5 \%)$

\section{Analysis And Discussions:}

In spite of the apparent opportunities in a country of our size and scope, Mutual Funds in India have not delivered anywhere close to potential. The corporate-centric focus still rules the roost in spite the retail-rich demographics of the country.

\section{Return Earned by the Schemes:}

Table 4.1 depicts the values of average returns earned by the Mutual Fund schemes as against the return on the stock market index for the period since inception date of the mutual fund scheme till July 2010.It shows that investment for longer period would get absolute higher return than the risk free rate of return $(5.5 \%)$. Reliance Regular Saving equities (20.95\%) have shown the highest return for the period of 3 years followed by UTI Dividend Yield (19.36\%). Out of 18 schemes, 2 schemes performed very poor (below risk free rate) for three year time period. Only one scheme has given negative return for the same time period. Further the performance of Private Sector Mutual fund schemes has been better than Private Sector Mutual fund schemes thus the first hypothesis under study is confirmed. In this study it was assumed that small sized funds are better than very large size firm as far as return is concerned but it is seen through analysis of 18 schemes that performance of the fund has no relation with its size i.e. some large sized funds have outperformed small size funds. 
A Comparative Study of Selected Public \& Private Sector Equity Diversified Mutual Fund...

Return Analysis of Equity Diversified Mutual Fund Schemes

\begin{tabular}{|c|c|c|c|c|c|c|c|c|}
\hline Scheme Name & 3 mnths & 6mnths & 1 year & 2 years & 3 years & 5 years & $\begin{array}{l}\text { Return } \\
\text { Since } \\
\text { Inception }\end{array}$ & $\begin{array}{l}\text { Fund Size } \\
\text { ( in Rs. } \\
\text { Crores) }\end{array}$ \\
\hline $\begin{array}{l}\text { Canara Robeco } \\
\text { Emerging Equities }\end{array}$ & $8.72 \%$ & $19.29 \%$ & $56.01 \%$ & $23.50 \%$ & $5.02 \%$ & $15.95 \%$ & $21.09 \%$ & 38.7 \\
\hline $\begin{array}{l}\text { Canara } \quad \text { Robeco } \\
\text { Equity Diversified }\end{array}$ & $5.20 \%$ & $13.41 \%$ & $39.23 \%$ & $26.01 \%$ & $13.70 \%$ & $22.13 \%$ & $27.57 \%$ & 331.2 \\
\hline $\begin{array}{l}\text { Canara Robeco } \\
\text { Infrastructure Fund }\end{array}$ & $2.95 \%$ & $8.71 \%$ & $24.51 \%$ & $17.39 \%$ & $8.48 \%$ & & $18.88 \%$ & 173.5 \\
\hline $\begin{array}{l}\text { Magnum Emerging } \\
\text { Businesses }\end{array}$ & $12.16 \%$ & $26.73 \%$ & $54.43 \%$ & $20.08 \%$ & $5.80 \%$ & $14.54 \%$ & $24.93 \%$ & 677.8 \\
\hline Magnum Equity & $8.31 \%$ & $17.87 \%$ & $26.00 \%$ & $16.19 \%$ & $10.36 \%$ & $22.84 \%$ & $15.94 \%$ & 2174.1 \\
\hline Magnum Mid Cap & $3.72 \%$ & $1.94 \%$ & $31.50 \%$ & $8.63 \%$ & $-4.22 \%$ & $15.02 \%$ & $16.32 \%$ & 14.3 \\
\hline $\begin{array}{l}\text { UTI Infrastructure } \\
\text { Fund }\end{array}$ & $4.12 \%$ & $7.21 \%$ & $12.36 \%$ & $5.85 \%$ & $2.40 \%$ & $18.70 \%$ & $24.36 \%$ & 1639 \\
\hline UTI Dividend Yield & $7.58 \%$ & $19.16 \%$ & $36.74 \%$ & $26.19 \%$ & $19.36 \%$ & $23.44 \%$ & $23.53 \%$ & 2233 \\
\hline UTI Opportunities & $6.47 \%$ & $15.12 \%$ & $24.94 \%$ & $24.75 \%$ & $15.76 \%$ & $19.53 \%$ & $19.82 \%$ & 1465.8 \\
\hline $\begin{array}{l}\text { Reliance Regular } \\
\text { Savings Equity }\end{array}$ & $7.91 \%$ & $16.03 \%$ & $33.87 \%$ & $23.03 \%$ & $20.95 \%$ & $25.19 \%$ & $23.83 \%$ & 2251.5 \\
\hline $\begin{array}{l}\text { Reliance Equity } \\
\text { Opportunities }\end{array}$ & $11.27 \%$ & $27.20 \%$ & $60.50 \%$ & $30.28 \%$ & $15.14 \%$ & $24.03 \%$ & $25.63 \%$ & 135.7 \\
\hline $\begin{array}{l}\text { Reliance } \quad \text { NRI } \\
\text { Equity }\end{array}$ & $8.52 \%$ & $19.37 \%$ & $30.43 \%$ & $27.10 \%$ & $11.76 \%$ & $22.59 \%$ & $26.65 \%$ & 498.4 \\
\hline $\begin{array}{l}\text { HDFC Premier } \\
\text { Multi Cap }\end{array}$ & $12.04 \%$ & $21.31 \%$ & $43.05 \%$ & $25.03 \%$ & $12.20 \%$ & $19.19 \%$ & $21.78 \%$ & 1360.7 \\
\hline HDFC Growth & $11.65 \%$ & $21.29 \%$ & $37.20 \%$ & $18.94 \%$ & $13.85 \%$ & $24.35 \%$ & $23.81 \%$ & 427.1 \\
\hline $\begin{array}{l}\text { HDFC Core \& } \\
\text { Satellite }\end{array}$ & $6.07 \%$ & $14.10 \%$ & $49.98 \%$ & $26.99 \%$ & $11.12 \%$ & $21.91 \%$ & $26.33 \%$ & 262.1 \\
\hline $\begin{array}{l}\text { Templeton India } \\
\text { Growth }\end{array}$ & $4.91 \%$ & $15.56 \%$ & $30.08 \%$ & $19.01 \%$ & $16.24 \%$ & $22.75 \%$ & $20.21 \%$ & 413.5 \\
\hline $\begin{array}{l}\text { Franklin India Flexi } \\
\text { Cap Fund }\end{array}$ & $4.15 \%$ & $8.60 \%$ & $31.81 \%$ & $22.09 \%$ & $8.57 \%$ & $22.48 \%$ & $23.16 \%$ & 324 \\
\hline $\begin{array}{l}\text { Franklin India Life } \\
\text { Stage- 20S Plan }\end{array}$ & $5.27 \%$ & $12.79 \%$ & $24.26 \%$ & $18.44 \%$ & $11.76 \%$ & $18.18 \%$ & $20.63 \%$ & \\
\hline
\end{tabular}

Table 4.1 
Performance analysis of Equity Diversified Schemes

\begin{tabular}{|c|c|c|c|c|c|c|c|}
\hline Scheme Name & SD & Beta & $\begin{array}{l}\text { Sharpe } \\
\text { Ratio }\end{array}$ & $\begin{array}{l}\text { Treynor } \\
\text { ratio }\end{array}$ & $\begin{array}{l}\text { Jensen } \\
\text { ratio }\end{array}$ & $\begin{array}{l}\text { R- } \\
\text { Squared }\end{array}$ & $\begin{array}{l}\text { P/E } \\
\text { Ratio }\end{array}$ \\
\hline $\begin{array}{lll}\text { Canara } & \text { Robeco } & \text { Emerging } \\
\text { Equities } & & \end{array}$ & 45.78 & 1.21 & 0.23 & 8.64 & 0.1 & 0.88 & 24.02 \\
\hline $\begin{array}{lll}\text { Canara } & \text { Robeco } & \text { Equity } \\
\text { Diversified } & & \end{array}$ & 36.8 & 1.02 & 0.45 & 16.3 & 7.77 & 0.96 & 21.82 \\
\hline $\begin{array}{l}\text { Canara Robeco Infrastructure } \\
\text { Fund }\end{array}$ & 42.58 & 1.17 & 0.08 & 2.92 & 4.95 & 0.96 & 22.4 \\
\hline Templeton India Growth & 35.51 & 0.97 & 0.48 & 17.78 & 7.98 & 0.93 & 17.66 \\
\hline Franklin India Flexi Cap Fund & 34.29 & 0.94 & 0.49 & 18.06 & 1.87 & 0.95 & 17.79 \\
\hline $\begin{array}{l}\text { Franklin India Life Stage- } 20 S \\
\text { Plan }\end{array}$ & 25.72 & 0.7 & 0.49 & 18.11 & 3.49 & 0.95 & 24.41 \\
\hline UTI Infrastructure Fund & 35.06 & 0.96 & 0.37 & 13.75 & -4.66 & 0.95 & 24.46 \\
\hline UTI Dividend Yield & 30.84 & 0.83 & 0.58 & 21.61 & 10.45 & 0.93 & 19.8 \\
\hline UTI Opportunities & 32.73 & 0.9 & 0.42 & 15.59 & 7.41 & 0.95 & 25.38 \\
\hline Reliance Regular Savings Equity & 41.37 & 1.08 & 0.47 & 18.23 & 12.67 & 0.87 & 35.54 \\
\hline Reliance Equity Opportunities & 37.35 & 1.01 & 0.5 & 18.35 & 7.21 & 0.92 & 24.45 \\
\hline Reliance NRI Equity & 36.7 & 0.99 & 0.47 & 17.26 & 4.07 & 0.93 & 21.49 \\
\hline HDFC Premier Multi Cap & 37.63 & 1.02 & 0.36 & 13.42 & 4.86 & 0.94 & 24.26 \\
\hline HDFC Growth & 32.16 & 0.88 & 0.59 & 21.42 & 5.43 & 0.95 & 20.88 \\
\hline HDFC Core \& Satellite & 37.7 & 1.02 & 0.44 & 16.09 & 4.36 & 0.92 & 21.83 \\
\hline Magnum Emerging Businesses & 48.44 & 1.25 & 0.18 & 7.23 & 1.95 & 0.85 & 23.83 \\
\hline Magnum Equity & 36.84 & 1.01 & 0.47 & 17.16 & 3.06 & 0.96 & 24.29 \\
\hline Magnum Mid Cap & 50.02 & 1.32 & 0.19 & 7.21 & -8.29 & 0.88 & 27.28 \\
\hline
\end{tabular}

\section{Systematic Risk (Beta and Standard Deviation}

Standard deviation measures the variation in individual from the average expected return over a certain period. Standard deviation shows the risk of portfolio of investments. SD is the deviation of the reading from the mean of the reading, higher SD indicates higher volatility and higher volatility and higher risk of the schemes. The first column of table 4.2 presents the systematic risk of the 18 mutual fund schemes. Beta shows the sensitivity of the return on the mutual fund scheme in comparison to the movement in the stock market index. Beta which measures the systematic risk shows how prices of securities respond to the market forces. Systematic risk is measured in term of beta which indicates the sensitivity of a schemes return in relation to market return. If a schemes beta is less than 1, it is considered to be defensive if the scheme beta is more than 1 it is consider being aggressive. Magnum Mid cap has highest standard deviation means higher risk followed by Magnum Emerging Businesses, Canara Robeco Emerging Equities and Canara Robeco Infrastructure Fund. Franklin India Life Stage- 20S Plan has the lowest standard deviation and the lowest beta. Beta value of higher than unity implies higher portfolio risk for the schemes than the market portfolio and vice-versa. Schemes namely Magnum Mid cap (1.32), Magnum Emerging Businesses (1.25), Canara Robeco Emerging Equities (1.21), Canara Robeco Infrastructure fund (1.17), Reliance Regular Saving equity (1.08), Canara Robeco Equity Diversified (1.02), HDFC Premier Multi Cap (1.02), HDFC Core \& Satellite (1.02) Magnum Equity (1.01) and Reliance Equity opportunities (1.01) were found to be more risky (beta $>1.0$ ) than the market. Remaining 8 mutual fund schemes had beta in the range of 0.88 to 0.99 except Franklin India Life Stage 20S Plan (0.70) holding portfolio with least risk among the lot. In the chart 1 below $\mathrm{X}$ axis represent Beta values and Y axis represent Mutual Fund Schemes. 


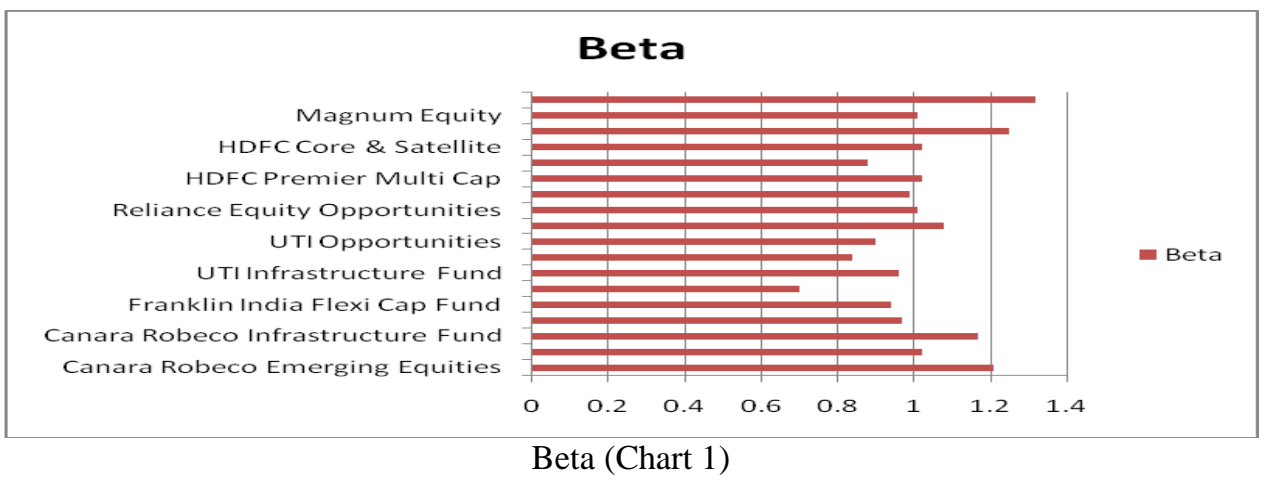

In the chart 2 below $\mathrm{X}$ axis represent Standard Deviation values and $\mathrm{Y}$ axis represent Mutual Fund Schemes.

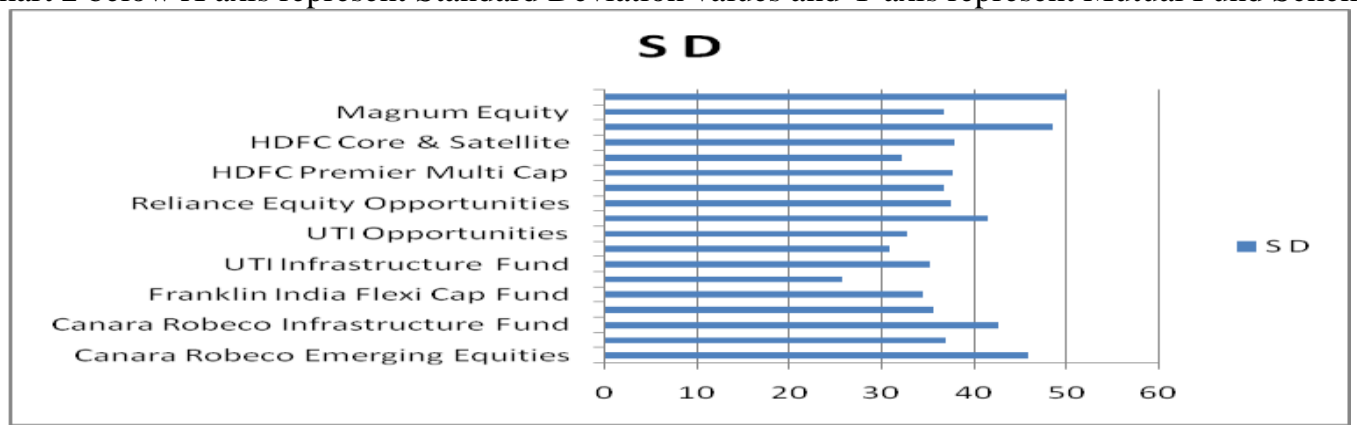

Standard Deviation (Chart 2)

\section{Results of Sharpe Ratio Measure}

Sharpe index is a measure of risk premium of a portfolio, relative to the total amount of risk in the portfolio. Sharpe index summarizes the risk and return of a portfolio in a single measure that categorizes the performance of Funds on the risk-adjusted basis. Column 3 of Table 4.2 shows the values of Sharpe ratio for the schemes. It is an excess returns earned over risk free return (Rf) per unit of risk i.e. per unit of Standard Deviation. Positive value of schemes indicates better performance. Higher positive values of Sharpe was found in HDFC Growth (0.59), Reliance Equity Opportunities (0.50), Franklin India Life Stage 20S Plan (0.49), Franklin India Flexi Cap (0.49), Templeton India Growth (0.48), Reliance Regular Saving Equity (0.47), Reliance NRI Equity (0.47) and HDFC Core \& Satellite (0.44) among the Private Sector Mutual Fund Schemes and UTI Dividend Yield (0.58), Magnum Equity (0.47), Canara Robeco Equity Diversified (0.45), UTI Opportunities (0.42), UTI Infrastructure Fund (0.37) among Public Sector Mutual Funds. Among the worst performers Canara Robeco Infrastructure Fund (0.08), Magnum Emerging Businesses (0.18), Magnum Midcap (0.18), Canara Robeco Emerging Equities (0.23) - Public Sector Mutual funds and HDFC Premier Multicap (0.36) - Private Sector Mutual Funds. On the whole Private Sector Mutual Funds led by Reliance outperform the Public Sector Mutual Funds as per the result shown by Sharpe Ratio. In the chart 3 below X axis represent Sharpe Ratios and Y axis represent Mutual Fund Schemes.

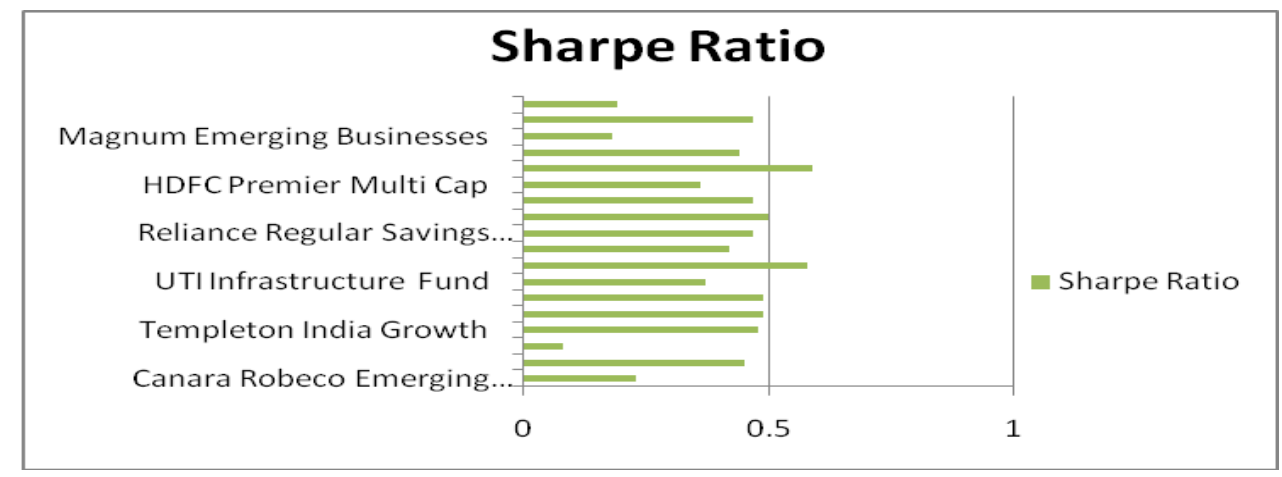

Sharpe Ratio (Chart 3) 


\section{Results Of Treynor Ratio Measure}

Treynor have provided the conceptual framework of relative measure of performance of mutual Funds. While Treynor used systematic risk, Sharpe used total risk to evaluate the mutual fund portfolio performance highest value of Treynor's index shows better performance of portfolio and vice versa. This index is known as reward to volatility ratio. The fourth column of Table 4.2 presents the Treynor ratio values for the individual mutual fund schemes. Here the observations were similar to that of Sharpe ratio with Private Sector Mutual Fund schemes outperforming Public Sector Mutual Fund Schemes except UTI Dividend Yield (21.61) showing outstanding performance. Among Private Sector Mutual fund schemes top performers HDFC Growth (21.42), Reliance Equity Opportunities (18.35), Reliance Regular Saving Equity (18.23), Franklin India Life Stage 20S Plan (18.11), Franklin India Flexi Cap Fund (18.06), Reliance NRI Equity (17.26), HDFC Core \& Satellite (16.09). Among Public Sector Mutual Fund Schemes UTI Dividend Yield (21.61), Magnum Equity (17.16), UTI Opportunities (15.59), UTI Infrastructure Fund (13.75), Canara Robeco Equity Diversified (16.30) .Canara Robeco Infrastructure Fund (2.62) was the worst performer mutual fund scheme. In the chart 4 below X axis represent Treynor Ratio and Y axis represent Mutual Fund Schemes.

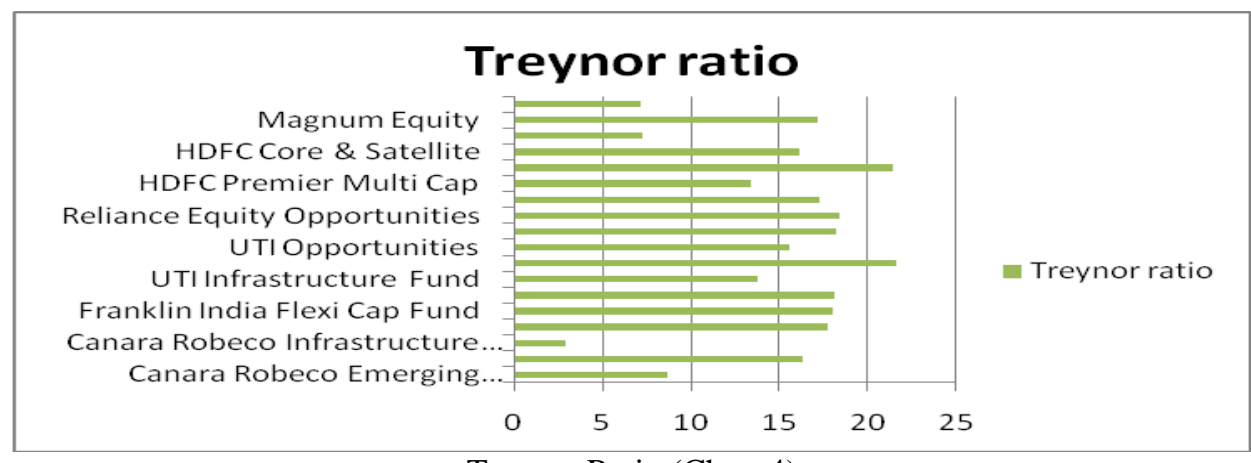

Treynor Ratio (Chart 4)

\section{Results of Jensen Ratio (Alpha)}

The size of the alpha depicts the stock's unsystematic returns and its average return independence of market return if the fund produces the expected return at the level of risk assumed, the fund would have an alpha equal to zero. A positive alpha indicates that the manager produced return greater than expected for the risk taken. Alpha is determined by comparing the fund's actual performance with the risk-adjusted expected return. The fifth column of Table 4.2 shows the Jensen Alpha values for 18 selected open ended Mutual fund growth schemes. It is the regression of excess return of the scheme (dependent variable) with excess return of the market (independent variable). Higher Alpha value indicates better performance. Among the public sector mutual fund, higher alpha was found with UTI Dividend Yield ( 10.45) followed by Canara Robeco Equity Diversified (7.77), UTI Opportunities (7.41) and Canara Robeco Infrastructure Fund (4.95). While in Private sector mutual funds higher performance was evidenced in Reliance Regular Saving Equity (12.67) followed by Templeton India Growth (7.98), Reliance Equity Opportunities (7.21), HDFC Growth (5.43), HDFC Premier Multicap (4.86) and HDFC Core \& Satellite (4.36). The worst performer was Magnum Mid cap (-8.29), UTI Infrastructure Fund (-4.66) - Public Sector mutual fund and Franklin India Flexi cap Fund (1.87),Franklin India Life Stage 20S Plan (3.49). Negative alpha values indicates the failure on the part of their fund managers to forecast security prices in time for taking better investment decision. Private sector mutual fund schemes showed better performance in comparison to Public sector mutual fund schemes as per the results shown by Jensen measure. In the chart 5 below X axis represent Mutual Fund Schemes and Y axis represent Jensen Ratio.

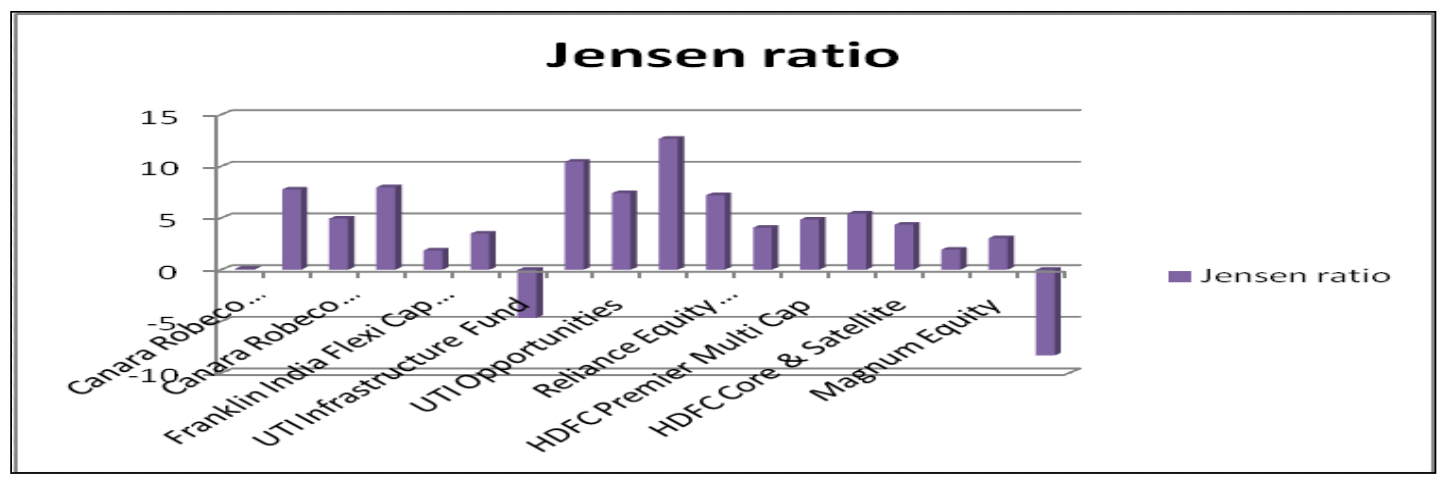

Jensen Ratio (Chart 5) 


\section{Coefficient of Determination $\left(\mathbf{R}^{2}\right)$}

The sixth column of Table 4.2 shows the value of coefficient of determination for each of the 18 mutual fund schemes considered for the purpose of this research work. Higher value of $\mathrm{R}^{2}$ shows higher diversification of the schemes portfolio that can easily contain market volatility. The highest value of coefficient of determination was found Magnum Equity (0.96), Canara Robeco Equity Diversified ( 0.96), Canara Robeco Infrastructure Fund (0.96), UTI Opportunities (0.95) among Public sector Mutual Fund schemes and Franklin India Flexi cap Fund (0.95), Franklin India Life Stage 20S Plan (0.95), HDFC Premier Multi cap (0.94), Templeton India Growth (0.93) among Private sector mutual fund schemes which indicates that these schemes have reasonably exploited the diversification strategy for forming their portfolio. Lower values of R-squared as witnessed in Magnum Emerging Businesses (0.85), Magnum Mid cap (0.88); Canara Robeco Emerging Equities (0.88) among public sector and Reliance Regular Saving Equities (0.87), HDFC Core \&Satellite (0.92), Reliance Equity Opportunities (0.92) suggest that these are inadequately diversified. In the chart 6 below X axis represent $\mathrm{R}$ Squared Value and Y axis represent Mutual Fund Schemes.

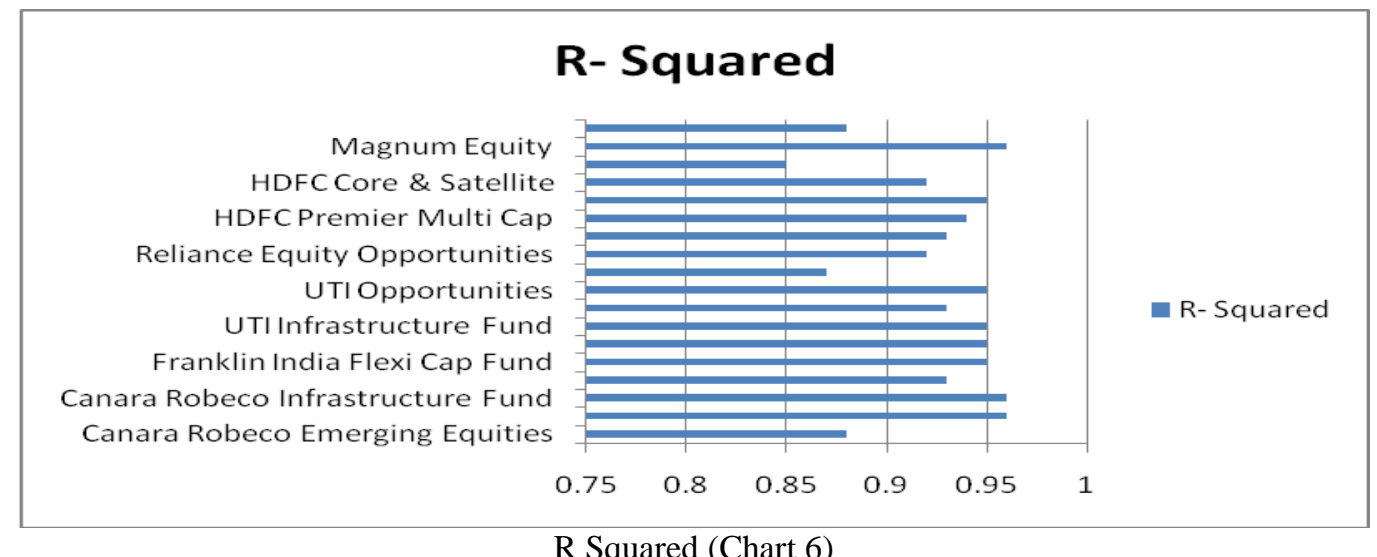

R Squared (Chart 6)

P/E Ratio: As shown in Table 4.2 Reliance Regular Saving Equities (35.54) has the highest value of P/E Ratio followed by Reliance Equity Opportunities (24.45), HDFC Franklin India Life Stage 20S (24.41)Premier Multi cap (24.26) among Private Sector Mutual Fund schemes. Among Public Sector Mutual Funds Magnum 0Mid Cap (27.28) was the highest followed by Magnum Equity (24.29), Canara Robeco Emerging Equities (24.02) and Canara Robeco Infrastructure Fund (22.40). In the chart 7 below X axis represent P/E Value and Y axis represent Mutual Fund Schemes.

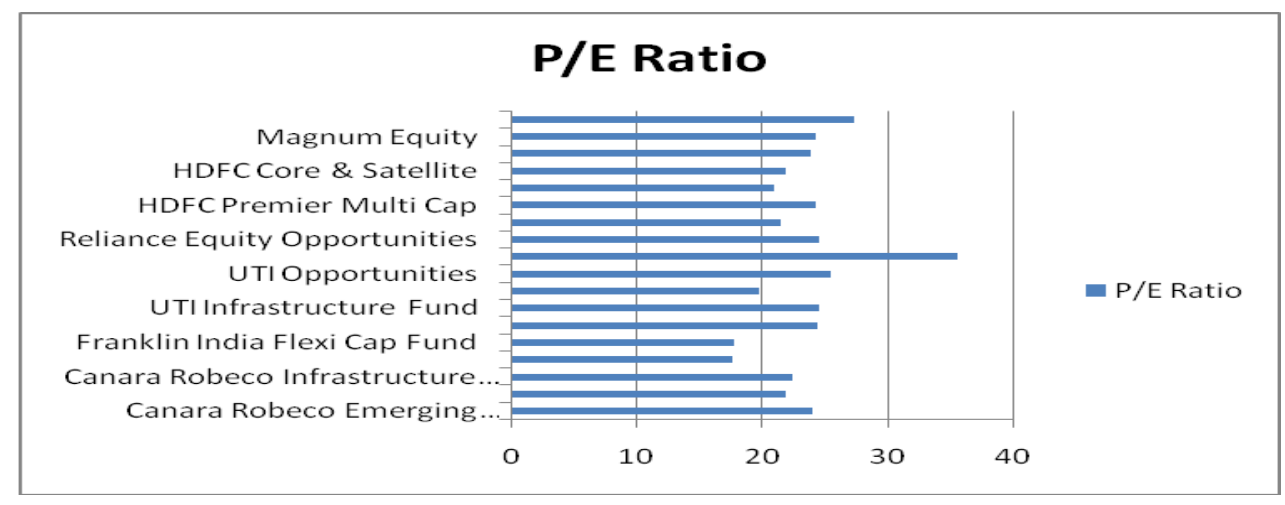

P/E Ratio (Chart 7) 
A Comparative Study of Selected Public \& Private Sector Equity Diversified Mutual Fund...

Performance of Equity Diversfied Mutual Fund schemes:

\begin{tabular}{|c|c|c|c|c|c|}
\hline Scheme Name & $\begin{array}{l}\text { Ranking by } \\
\text { Sharpe }\end{array}$ & $\begin{array}{l}\text { Ranking by } \\
\text { Treynor }\end{array}$ & $\begin{array}{l}\text { Ranking } \\
\text { by Jensen }\end{array}$ & $\begin{array}{l}\text { Ranking by } \\
\text { P/E }\end{array}$ & $\begin{array}{l}\text { Ranking } \\
\text { by Beta }\end{array}$ \\
\hline $\begin{array}{l}\text { Canara Robeco } \\
\text { Emerging Equities }\end{array}$ & 12 & 15 & 16 & 9 & 13 \\
\hline $\begin{array}{l}\text { Canara Robeco } \\
\text { Equity Diversified }\end{array}$ & 7 & 10 & 4 & 13 & 10 \\
\hline $\begin{array}{ll}\text { Canara } & \text { Robeco } \\
\text { Infrastructure Fund }\end{array}$ & 15 & 18 & 8 & 11 & 12 \\
\hline $\begin{array}{l}\text { Templeton India } \\
\text { Growth }\end{array}$ & 5 & 7 & 3 & 18 & 7 \\
\hline $\begin{array}{l}\text { Franklin India Flexi } \\
\text { Cap Fund }\end{array}$ & 4 & 6 & 15 & 17 & 5 \\
\hline $\begin{array}{l}\text { Franklin India Life } \\
\text { Stage- 20S Plan }\end{array}$ & 4 & 5 & 12 & 6 & 1 \\
\hline $\begin{array}{l}\text { UTI Infrastructure } \\
\text { Fund }\end{array}$ & 10 & 13 & 17 & 4 & 6 \\
\hline UTI Dividend Yield & 2 & 1 & 2 & 16 & 2 \\
\hline UTI Opportunities & 9 & 12 & 5 & 3 & 4 \\
\hline $\begin{array}{l}\text { Reliance Regular } \\
\text { Savings Equity }\end{array}$ & 6 & 4 & 1 & 1 & 11 \\
\hline $\begin{array}{l}\text { Reliance } \quad \text { Equity } \\
\text { Opportunities }\end{array}$ & 3 & 3 & 6 & 5 & 9 \\
\hline Reliance NRI Equity & 6 & 8 & 11 & 14 & 8 \\
\hline $\begin{array}{l}\text { HDFC Premier Multi } \\
\text { Cap }\end{array}$ & 11 & 14 & 9 & 8 & 10 \\
\hline HDFC Growth & 1 & 2 & 7 & 15 & 3 \\
\hline $\begin{array}{l}\text { HDFC Core \& } \\
\text { Satellite }\end{array}$ & 8 & 11 & 10 & 12 & 10 \\
\hline $\begin{array}{l}\text { Magnum Emerging } \\
\text { Businesses }\end{array}$ & 14 & 16 & 14 & 10 & 14 \\
\hline Magnum Equity & 6 & 9 & 13 & 7 & 9 \\
\hline Magnum Mid Cap & 13 & 17 & 18 & 2 & 15 \\
\hline
\end{tabular}

Table 4.3

Ranking of Mutual Fund Schemes: Table 4.3 shows the ranking of the schemes from the different measurement of the portfolio evaluation of selected Public and Private Sector Mutual Fund schemes.

\section{Ranking By Beta}

Magnum Midcap (1.32) has the highest Beta value so it is the first choice for the risk taker investors. It is followed by Magnum Emerging Businesses (1.25), Canara Robeco Emerging Equities (1.21), Canara Robeco Infrastructure Fund (1.17) and Reliance Regular Saving Equities (1.08) while Franklin India Life Stage $20 \mathrm{~S}$ plan has least Beta. 


\section{Ranking By Sharpe Index:}

HDFC Growth Fund is the best scheme among the peers as it has maximum Sharpe ratio. It gets the first rank according to Sharpe ratio. UTI Dividend Yield is on the second position and Reliance Equity Opportunities is on third position followed by Franklin India Flexi cap, Franklin India Life Stage Fund and Templeton India Growth.

\section{Ranking By Treynor Ratio}

UTI Dividend Yield is on top position as per Treynor Ratio. HDFC Growth Fund is on second rank. Reliance Equity Opportunities gets third position followed by Reliance Regular Saving Equities, Franklin India Life Stage Fund and Franklin India Flexi cap.

Ranking by Jensen (Alpha): According to Jensen Index Reliance Regular saving Equities is on top, second rank goes to UTI Dividend Yield; third position goes to Templeton India Growth Fund followed by Canara Robeco Equity Diversified, UTI Opportunities and Reliance Equity Opportunities Fund.

Ranking by P/E Ratio: According to P/E Ratio, Reliance Regular saving Equities is on top, second rank goes to Magnum Mid Cap followed by UTI Opportunities, UTI Infrastructure Fund and Reliance Equity Opportunities

\section{Ranking by Beta}

According to Beta Franklin India Life Stage- 20S Plan has the lowest the lowest beta hence ranked $1^{\text {st }}$ as it is involve least risk. The other schemes with less beta values are UTI dividend yield, HDFC Growth and UTI opportunities.

\section{Conclusion}

The favorite sector for Equity Diversified Mutual Fund schemes is Energy followed by banking, technologies, communication and engineering. Private sector mutual fund schemes are performing better than Public sector mutual fund schemes. It shows that investment for longer period would get absolute higher return than the risk free rate of return. Magnum Midcap has highest beta means higher risk followed by Magnum Emerging Businesses and Canara Robeco Emerging Equities Fund. Franklin India Life Stage 20S Fund has lowest beta which can be a good investment option for risk adverse investors. HDFC Growth Fund has highest Sharpe Ratio among Public and Private Sector Mutual Fund schemes. UTI Dividend Yield has highest Treynor Ratio followed by HDFC Growth Fund, Reliance Equity Opportunities and Reliance Regular Saving Equities. Reliance Regular Saving Equities has highest Jensen ratio value followed by UTI Dividend Yield, Templeton India Growth and Canara Robeco Equity Diversified.

The highest value of Coefficient of Determination was found in Magnum Equity followed by Canara Robeco Equity Diversified, Canara Robeco Infrastructure fund and UTI Opportunities in case of Public Sector Mutual fund whereas in case of Private Sector Mutual Fund Franklin India Flexi cap followed by Franklin India Life Stage 20 S Fund and HDFC Premier Multi cap. Reliance Regular Saving Equities has highest P/E ratio value.

\section{References}

[1]. Debasish, Sathya Swaroop, Performance Evaluation Choice Funds, SCMS Journal of Indian Management, January- March 2007.

[2]. Gupta, Amitabh, "Market Timing Abilities of Indian Mutual Fund Managers: An Empirical Study." The ICFAI Journal of Applied Finance. Vol. 6, No.2, April 47-60, 2000.

[3]. Jayadev, N., "Mutual Fund Performance: An analysis of Monthly Returns" Finance India, Vol. X No.1, March 1996.

[4]. Jensen, M.C, (1968), "The Performance of Mutual Funds", Journal of Finance, Vol. 23, No.2. "The Performance of Mutual Funds In The Period 1945 - 1964", Journal Of Finance (May 1968)

[5]. Panwar,Sharad and Dr. Madhumathi (2006), "Characteristics and performance evaluation of selected mutual funds in India", www.ssrn.com, paper no.876402 and pp. 1-19

[6]. Rao, P Hanumantha and Mishra, Vijay Kumar, "Mutual Fund: A Resource Mobilizer in Financial Market". Vidyasagar University Journal of Commerce. Vol. 12, March 2007

[7]. Sarkar, A.K., (1991) "Performance Evaluation of Mutual Funds", Management Accountant, 9: 691-693.

[8]. Tripathy, Nalini Prava and Panda, Tapan K. , Customer Orientation in Designing Mutual Fund Products -An Analytical Approach to Indian Market Preferences

[9]. Tripathy, Nalini Prava, "Mutual Fund In India: A Financial Service In Capital Market” Finance India, Vol. X No. 1, Pages- 85-91, March 1996

[10]. http://www.mutualfundindia.com

[11]. http://www.amfiindia.com

[12]. http://www.nseindia.com

[13]. http://www.bseindia.com

[14]. http://navindia.com

[15]. http://www.valueresearchonline.com

[16]. http://.www.icraonline.com

[17]. http://www.sebi.gov.in

[18]. http://business.mapsofindia.com/investment-industry/mutual-fundinvestment.html 
[19]. Business Today, April 3,2011

[20]. Business World, March 28,2011

[21]. Outlook Money, May 6,2009

[22]. Indian Mutual Fund Industry - Towards 2015 Sustaining Inclusive Growth - Evolving Business Models (Price Water House Coopers)

[23]. SEBI Manual $16^{\text {th }}$ Edition, Taxman Publications Pvt. Ltd. , 2010

[24]. Banerjee, Arindam, Indian Capital Market - Trends and Reforms, The ICFAI University Press, Edition 2006

[25]. Banerjee, Arindam, Mutual Funds in India - Perspectives \& Strategies

[26]. Bhalla, V. K. (2001), "Investment Management: Security Analysis \& Portfolio Management”, S. Chand, Delhi.

[27]. Chandra, (2002) "Investment Analysis and Portfolio Management", Tata McGraw Hill. New Delhi

[28]. Goddard, Wayne and Melville, Stuart, Research Methodology - An Introduction, Juta and Company Ltd., 2004

[29]. Khan, J. A., Research Methodology, APH Publishing Corporation, New Delhi, 2008

[30]. Khan, The Indian Financial System, Tata McGraw Hill Education, 2006

[31]. Sadhak, H., Mutual Funds in India "Marketing Strategy and Investment Practices, Second Edition 2003

[32]. Sahadevan, K. G., Thiripalraju, M., Mutual Funds: Data, Interpretation and Analysis, Prentice Hall of India Private Limited, New Delhi, 1997

[33]. Srivastava, R.M. and Nigam Divya, Management of Indian Financial Institutions, Eight Revised Edition, Himalaya Publishing House 